\title{
TELOMERIZED FIBROBLASTS AS A CANDIDATE 3D IN VITRO MODEL OF PATHOLOGICAL HYPERTROPHIC SCARS
}

Shadrin VS $\otimes$, Kozhin PM, Shoshina OO, Luzgina NG, Rusanov AL

Orekhovich Research Institute of Biomedical Chemistry, Moscow, Russia

\begin{abstract}
The search for the optimal cell model for studying the pathogenesis of pathological scars is a pressing challenge. This study aimed at evaluating the feasibility of using telomerized fibroblasts for the in vitro 3D modeling of pathological hypertrophic scars. NF and Fb-hTERT cells were cultured as monolayers and spheroids in the absence and in the presence of TGF $\beta 1$. The metabolic activity of the cultured cells was assessed using the MTT assay. Cell migration was estimated using the scratch assay. The expression of genes associated with fibrous scar tissue growth was measured by qRT-PCR. Fb-hTERT cells were more metabolically active than NF cells in the presence of TGF $\beta 1$ (for $1 \mathrm{ng} / \mathrm{ml}: 179 \pm 12 \%$ vs. $135 \pm 13 \%$ respectively; $p<0,05$ ). Spheroids grown from Fb-hTERT cells were significantly larger than those derived from NF cells. In the presence of TGF $\beta 1$, the expression of proteins associated with extracellular matrix production (COL1A1, COL3A1, FN1) was lower in Fb-hTERT cells than in NF cells (more than 25, 20 and 2-fold, respectively; $p<0.05$ ). Intact NF cells were more active in closing the scratch than Fb-hTERT cells: on day 2, the gap closure rate was 2.28 times higher in NF cells $(p<0.05)$. Exposure to TGF $\beta 1$ stimulated Fb-hTERT, unlike NF cells, to close the gap 2 times faster on day $2(p<0.05)$. Thus, telomerized fibroblasts have a few phenotypic traits observed in keloid fibroblasts; still there are some limitations that should be accounted for when using Fb-hTERT cells for the modeling of pathological hypertrophic scars.
\end{abstract}

Keywords: in vitro model, fibroblasts, hTERT, hypertrophic scar, keloid scar, TGF $\beta 1$

Funding: this research was supported by the Russian Ministry of Science and Higher Education and was conducted under the Federal Targeted Program on Research and Development in Priority Fields of Science and Technology for 2014-2020 (Agreement 05.604.21.0219, Project ID RFMEFI60419X0219).

Author contribution: Luzgina NG, Rusanov AL conceived the study and proposed its design; Shadrin VS, Kozhin PM, Shoshina OO, Luzgina NG, Rusanov AL analyzed the literature, analyzed and interpreted the experimental data and wrote the manuscript; Shadrin VS, Kozhin PM planned and conducted the experiment; Shadrin VS wrote the manuscript.

$\triangle$ Correspondence should be addressed: Valerian S. Shadrin

Pogodinskaya, 10, str. 8, Moscow, 119121; valerianshadrin@gmail.com

Received: 28.08.2020 Accepted: 02.09.2020 Published online: 27.09.2020

DOI: $10.24075 /$ brsmu.2020.057

\section{ТЕЛОМЕРИЗОВАННЫЕ ФИБРОБЛАСТЫ КАК ПОТЕНЦИАЛЬНЫЙ ОБЪЕКТ ДЛЯ ЗD-МОДЕЛИРОВАНИЯ ПАТОЛОГИЧЕСКИХ ГИПЕРТРОФИЧЕСКИХ РУБЦОВ IN VITRO}

\author{
В. С. Шадрин $₫$, П. М. Кожин, О. О. Шошина, Н. Г. Лузгина, А. Л. Русанов
}

Научно-исследовательский институт биомедицинской химии имени В. Н. Ореховича, Москва, Россия

\begin{abstract}
Поиск оптимальных клеточных моделей для изучения патогенеза гиперпластических рубцов является актуальной задачей. Целью исследования было оценить перспективу использования теломеризованных фибробластов в качестве объекта при 3D-моделировании патологических гипертрофических рубцов in vitro. Клетки НФ и Фб-hТЕRТ культивировали в виде монослоя и сфероидов, в интактном состоянии и при воздействии ТGFß1. Метаболическую активность клеток оценивали методом МТТ. Скорость зарастания дефекта монослоя клеток вычисляли с помощью sсratch-теста. Уровень экспрессии генов, ассоциированных с гиперпластическими процессами, определяли методом qRT-PCR. Для Фб-hTERT характерно более выраженное по сравнению с НФ усиление метаболической активности клеток при воздействии ТGF $\beta 1$ (для 1 нг/мл $179 \pm 12 \%$ и $135 \pm 13 \%$ соответственно; $р$ < 0,05). Сфероиды, сформированные из Фб-hTERT, были значительно крупнее сфероидов, полученных из НФ. Продукция основных специфичных для фибробластов белков, ассоциированных с продукцией внеклеточного матрикса (COL1A1, COL3A1, FN1), при стимуляции TGFß1 была ниже в Фб-hTERT по сравнению с НФ (более чем в 25, 20 и 2 раза соответственно; $p<$ 0,05). Интактные НФ более активно, по сравнению с Фб-hТЕRT, восстанавливали десект монослоя (в 2,28 раза на вторые сутки; $p<0,05)$. При этом воздействие TGF $\beta 1$ приводило к увеличению скорости заполнения десекта клетками Фб-hТЕRT (в 2 раза на вторые сутки; $p<0,05)$, но не НФ. Таким образом, теломеризованные фибробласты имеют ряд фенотипических признаков, характерных для келоидных фибробластов, но в то же время есть ограничения, которые следует учитывать при использовании Фб-hТЕRT для моделирования патологических гипертрофических рубцов.
\end{abstract}

Ключевые слова: in vitro модель, фибробласты, hTERT, гипертросический рубец, келоидный рубец, TGF $\beta 1$

Финансирование: работа выполнена при финансовой поддержке Министерства науки и высшего образования Российской Федерации в рамках ФЦП «Исследования и разработки по приоритетным направлениям развития научно-технологического комплекса России на 2014-2020 годы» (соглашение № 05.604.21.0219, Уникальный идентификатор проекта RFMEFI60419X0219).

Вклад авторов: Н. Г. Лузгина, А. Л. Русанов - концепция и дизайн исследования; В. С. Шадрин, П. М. Кожин, О. О. Шошина, Н. Г. Лузгина, А. Л. Русанов - анализ литературы, анализ и интерпретация полученных данных, редактирование рукописи; В. С. Шадрин, П. М. Кожин - планирование и проведение исследования; В. С. Шадрин - написание статьи.

$\searrow$ Для корреспонденции: Валериан Сергеевич Шадрин

ул. Погодинская, д. 10, стр. 8, г. Москва, 119121; valerianshadrin@gmail.com

Статья получена: 28.08.2020 Статья принята к печати: 02.09.2020 Опубликована онлайн: 27.09.2020

DOI: $10.24075 /$ vrgmu.2020.057

Every year, over 100 million people worldwide develop skin scars after surgical interventions, injuries or burns. Wounds heal differently depending on their location, depth, healing conditions, and clinical characteristics of the affected patients; wound repair can culminate in the formation of a normal (normotrophic) or pathological scar. Stimulated by a variety of factors, abnormal fibrous tissue growth leads to hypertrophic and keloid scarring. Both types of scarring are a cutaneous fibroproliferative disorder characterized by the hyperactivation of fibroblasts in the wound and excessive proliferation of extracellular matrix [1].

The absence of simple and cost-effective in vitro cell models replicating profibrogenic pathways makes it difficult to explore 
the pathogenesis of hypertrophic and keloid scarring and to develop effective preventive and curative treatments. Fibroblasts isolated from keloid tissue vary in phenotype between donors; besides obtaining the sufficient amount of clinical keloid tissue specimens is a real challenge. Therefore, the search for the optimal cell model for reproducing the phenotype of keloid fibroblasts is a pressing concern. It seems promising to use immortalized cell lines that can proliferate indefinitely and retain a stable phenotype at high passage numbers.

It is known that keloid fibroblasts are characterized by high proliferative activity, rapid growth, increased expression of collagen I, fibronectin, elastin, periostin (regulates production of collagen I), and tenascin (participates in cell adhesion) $[2,3]$, resulting in extensive connective tissue growth beyond the borders of the injury. Some aspects of keloid fibroblast metabolism are similar to those of tumor cells $[4,5]$.

It is hypothesized that the fibroblast phenotype observed in pathological scars is determined by high telomerase activity [6]. A research team was able to suppress proliferation and growth of keloid fibroblasts and normalize some of their phenotypic traits by decreasing telomerase activity in these cells; the authors concluded that telomerase inhibition might be a promising strategy for keloid therapy [5]. Therefore, it would be interesting to evaluate the potential of telomerized fibroblasts for the in vitro modeling of pathological scarring.

Optimization of cell culture techniques is crucial for designing an adequate scarring model. It is known that the center of keloid tissue is often hypoxic due to capillary occlusion resulting from excess collagen and endothelial cells [7]. Fibroblasts at the margins are more metabolically active, invasive, and capable of activating angiogenesis, presumably for maintaining their invasiveness [8]. Therefore, models utilizing spheroid cell culture systems look very attractive.

Transforming growth factor $\beta 1$ (TGF $\beta 1$ ) is often used to induce the profibrogenic fibroblast phenotype in vitro [9]. This multifunctional protein regulates cellular growth, differentiation, motility, and production of extracellular matrix during normal tissue healing; importantly, increased expression of TGF $\beta 1$ can trigger fibrotic skin disorders [10]. TGF $\beta 1$ stimulates collagen growth and secretion and induces fibronectin synthesis in keloid fibroblasts [11]. It would be interesting to evaluate the functional response of model cell candidates to TGF $\beta 1$.

The aim of this study was to evaluate the feasibility of using telomerized fibroblasts for the in vitro 3D modeling of hypertrophic scars

\section{METHODS}

\section{Cell lines}

The study was carried out using normal (NF) and telomerized (Fb-hTERT) human skin fibroblasts. Primary third-passage NF isolated from the foreskin of 35-38-year-old donors were purchased from a cryobank (Perspective; Russia). In order to account for different phenotypic traits of cells obtained from different donors, three cell lines were used.

Fb-hTERT cells were a gift from Prof. Egorov EE. (Engelhardt Institute of Molecular Biology, RAS). They are a HAF-1608 cell culture with the telomerase catalytic subunit gene. Fb-hTERT cells maintain a stable phenotype over up to 200 passages [12].

\section{Culture}

The cells were cultured in a complete DMEM/F-12 (Gibco; USA) medium supplemented with 10\% FBS (Dia-M; Russia),
$1 \%$ antibiotic-antimycotic solution by Gibco, USA (final concentrations: $100 \mathrm{un} / \mathrm{ml}$ penicillin, $0.25 \mu \mathrm{g} / \mathrm{ml}$ amphotericin B, $100 \mathrm{un} / \mathrm{ml}$ streptomycin) and 1\% GlutaMAX solution by Gibco, USA (the final concentration of L-alanyl-L-glutamine was $2 \mathrm{mM}$ ).

\section{MMT-based analysis of TGF $\beta 1$ effect on cells}

For the MTT assay [13], 2,500 NF cells at passage 4 and FbhTERT cells harvested at $70 \%$ confluency from the culture flask were plated in each well of a flat-bottom 96-well plate and incubated for $24 \mathrm{~h}$ in a complete DMEM/F-12 medium at $37{ }^{\circ} \mathrm{C}$ and $5 \% \mathrm{CO}_{2}$. Then, the medium was replaced with a fresh medium containing TGF $\beta 1$ (ProSpec; Israel), and the cells were incubated for another $48 \mathrm{~h}$, the medium being changed every $24 \mathrm{~h}$. After that, the medium was collected and the wells were washed in DPBS (Gibco; USA); $100 \mu \mathrm{l}$ of $1 \mathrm{mg} / \mathrm{ml}$ MTT solution (Dia-M; Russia) was added to each well, and the cells were incubated for $2.5 \mathrm{~h}$ at $37^{\circ} \mathrm{C}$ and $5 \% \mathrm{CO}_{2}$. After $2.5 \mathrm{~h}$ of incubation, the MTT solution was replaced with DMSO (Biolot; Russia) and the mixture was further incubated at room temperature until formazan crystals were completely solubilized. Absorbance was measured in each well at $490 \mathrm{~nm}$; background absorbance at $655 \mathrm{~nm}$ was subtracted. The MTT assay was run in 3 replicates ( 5 wells per replicate) using the following TGF $\beta 1$ concentrations: $0 \mathrm{ng} / \mathrm{ml} ; 0.1 \mathrm{ng} / \mathrm{ml} ; 1 \mathrm{ng} / \mathrm{ml}$; $5 \mathrm{ng} / \mathrm{ml} ; 10 \mathrm{ng} / \mathrm{ml}$.

Cell metabolic activity was calculated using the formula: $100 \%$ * $\left(\mathrm{AB}_{490}\right.$ (experimental wells) $-\mathrm{AB}_{490}$ (medium) $) /\left(\mathrm{AB}_{655}\right.$ (control wells) $-\mathrm{AB}_{655}$ (medium)). AB stands for absorbance.

\section{Spheroid cell culture}

Spheroids were grown in ultra-low attachment 96-well plates (Corning; USA); 5, 10 or 20 thousand NF or Fb-hTERT cells at $70 \%$ confluency were dispensed into the wells and incubated for 9 days in a complete DMEM/F-12 medium at $37^{\circ} \mathrm{C}$ and $5 \%$ $\mathrm{CO}_{2}$. The medium was replaced every $24 \mathrm{~h}$.

To study the effect exerted by TGF $\beta 1$ on spheroids, 20,000 NF cells and 10,000 Fb-hTERT cells (sufficient for growing spheroids of comparable sizes) harvested at $70 \%$ confluency from culture flasks were dispensed into each well and incubated for 3 days in a complete DMEM/F-12 medium supplemented with $1 \mathrm{ng} / \mathrm{ml}$ TGF $\beta 1$ at $37^{\circ} \mathrm{C}$ and $5 \% \mathrm{CO}_{2}$. The medium was replaced every $24 \mathrm{~h}$ to maintain stable concentrations of the growth factor.

Spheroids were photographed every day using a Primovert microscope (Carl Zeiss; Germany). Their diameters were measured using Image J software and a Fiji extension (National Institutes of Health; USA) [14].

\section{Estimating wound closure rate in cell monolayer using scratch assay}

Harvested at $70 \%$ confluency from a culture flask, 50,000 NF or Fb-hTERT cells were added to each well of a 24-well plate and incubated for $24 \mathrm{~h}$ in a complete DMEM/F-12 medium at $37^{\circ} \mathrm{C}$ and $5 \% \mathrm{CO}_{2}$ until the monolayer was formed. Then the medium was replaced, and a scratch was made on the cell monolayer with a $1 \mathrm{ml}$-pipet tip. The cells were washed in DPBS; then, DMEM/F-12 (control) or DMEM/F-12 containing $1 \mathrm{ng} / \mathrm{ml}$ TGF $\beta 1$ (experiment) was added to the cells. The cells were incubated for 2 days. In each well, the entire length of the scratch was photographed daily. The photos were processed in CellProfiler (Broad Institute of Harvard and MIT; USA) [15]. The closed area of the gap was calculated at 24 and 48 h; 
the ratio of the closing gap area to the initial scratch area was calculated. The experiment was conducted in 3 replicates in 3 wells per replicate.

\section{Measuring expression of genes associated with abnormal fibrous growth using qRT-PCR}

After analyzing the literature, we chose the PAI-1 gene and the genes encoding synthesis of collagen I, collagen III and fibronectin as target genes. Obviously, this list is not exhaustive but the increased expression of these genes suggests modulation of profibrogenic cell potential.

Briefly, qRT-PCR was performed as described below. The suspension of 200,000 cells in $5 \mathrm{ml}$ of the culture medium was transferred to a flask and preincubated for $48 \mathrm{~h}$ in a complete DMEM/F-12 medium at $37^{\circ} \mathrm{C}$ and $5 \% \mathrm{CO}_{2}$. Then, the medium was replaced with a fresh medium containing $1 \mathrm{ng} / \mathrm{ml}$ TGF $\beta 1$ and the cells were incubated for another 48 . The medium was replaced every $24 \mathrm{~h}$. After that, RNA was isolated from the cells using an RNeasy Mini Kit (Qiagen; Germany) according to the standard protocol. The obtained RNA was quantified on a NanoDrop 2000c spectrophotometer (Thermo Scientific; USA). Reverse transcription was performed following the standard protocol using an MMLV RT kit (Evrogen; Russia) and $1 \mu \mathrm{g}$ of RNA. qPCR was performed using a gPCRmix-HS SYBR+LowROX reaction mix (Evrogen; Russia). For each gene and each sample, the reaction was run in 3 replicates. GAPDH was chosen as a reference gene.

Primers are listed below:

GAPDH Forward Primer F: 5'-TCGACAGTCAGCCGCATCTTC TाT-3' ReversePrimerR:5'-ACCAAATCCGTTGACTCCGACCTT-3'; COL1A1 F: 5'-CCAAGAGGAAGGCCAAGTC-3' R: 5'-ACAC GTCTCGGTCATGGTA-3'; COL3A1 F: 5'-CTGGTGCTAAG GGTGAAGTT-3' R: 5'-GTCCAGGTTCTCCTCTTTGTC-3'; FN1 F: 5'-GAATAAGCTGTACCATCGCAAAC-3' R: 5'-ACCAAG ACACACACACTCTAAC-3'; PAl-1 F: 5'-GGCTGACTTC ACGAGTCTT-3' R: 5'-CGTTCACCTCGATCTTCACTT-3';

\section{Measuring collagen I production by spheroid culture}

Spheroids were grown as described above. After 3 days of incubation, spheroids grown from 10,000 cells were fixed in $4 \%$ formalin and embedded in paraffin following the standard protocol. Paraffin sections were stained with goat anti-human collagen I primary antibodies (IMTEK; Russia) and donkey antigoat IgG FITC secondary antibodies (ab6881, Abcam; USA). Three spheroid samples per each cell line were chosen for the analysis; for further staining, we used 5 paraffin sections per sample. All sections were stained simultaneously using the same reagent kit (antibody solutions and buffers).

The stained paraffin sections were examined under a laser confocal LSM 710 microscope (Carl Zeiss; Germany); in all cases, the settings were identical. Photographs were processed in CellProfiler [15]. For each sample, the mean fluorescence intensity was calculated as the total fluorescence intensity divided by the spheroid area. Mean fluorescence intensity values were normalized to the mean fluorescence intensity of NF cells that had not been exposed to TGF $\beta 1$.

\section{Statistical analysis}

The obtained data were processed using the programming language $\mathrm{R}$. Differences between the groups were tested using Student's $t$ test with the Benjamini-Hochberg procedure for multiple comparisons. Differences were considered significant at $p<0.05$. Statistical data are presented below as $\mathrm{M} \pm m$ unless specified otherwise.

\section{RESULTS}

Normal and immortalized skin fibroblasts differed in their size and proliferative activity. The surface area of NF cells cultured at low density (> 50\% confluency) was $723 \pm 54 \mu \mathrm{m}^{2}$ (Fig. 1A).

Doubling time was calculated by the formula DT $=T^{*} \ln 2 /$ In $\left(X_{1} / X_{0}\right)$, where $T$ is incubation time, $X_{1}$ is the number of cells after culture, $X_{0}$ is the initial number of cells. For NF cells, doubling time was $3.1 \pm 0.6$ days. Cultured as a monolayer, NF cells reached $100 \%$ confluence at a density of $16.5 \pm 3.1 * 10^{3} \mathrm{cells} / \mathrm{cm}^{2}$.

The surface area of Fb-hTERT cells was smaller: $675 \pm 29 \mu \mathrm{m}^{2}$ (Fig. 1A). Doubling time was $1.8 \pm 0.4$ days. Fb-hTERT cells reached $100 \%$ confluence at $41.9 \pm 7.2{ }^{*} 10^{3} \mathrm{cells} / \mathrm{cm}^{2}$.

The MTT assay revealed a dose-dependent effect of TGF $\beta 1$ on NF and Fb-hTERT cultures (Fig. 1B). The metabolic activity of Fb-hTERT and NF increased significantly after the cells were treated with $0.1 \mathrm{ng} / \mathrm{ml}$ and $1 \mathrm{ng} / \mathrm{ml}$ of TGF $\beta 1$, respectively. For both cell lines, a peak in the metabolic activity
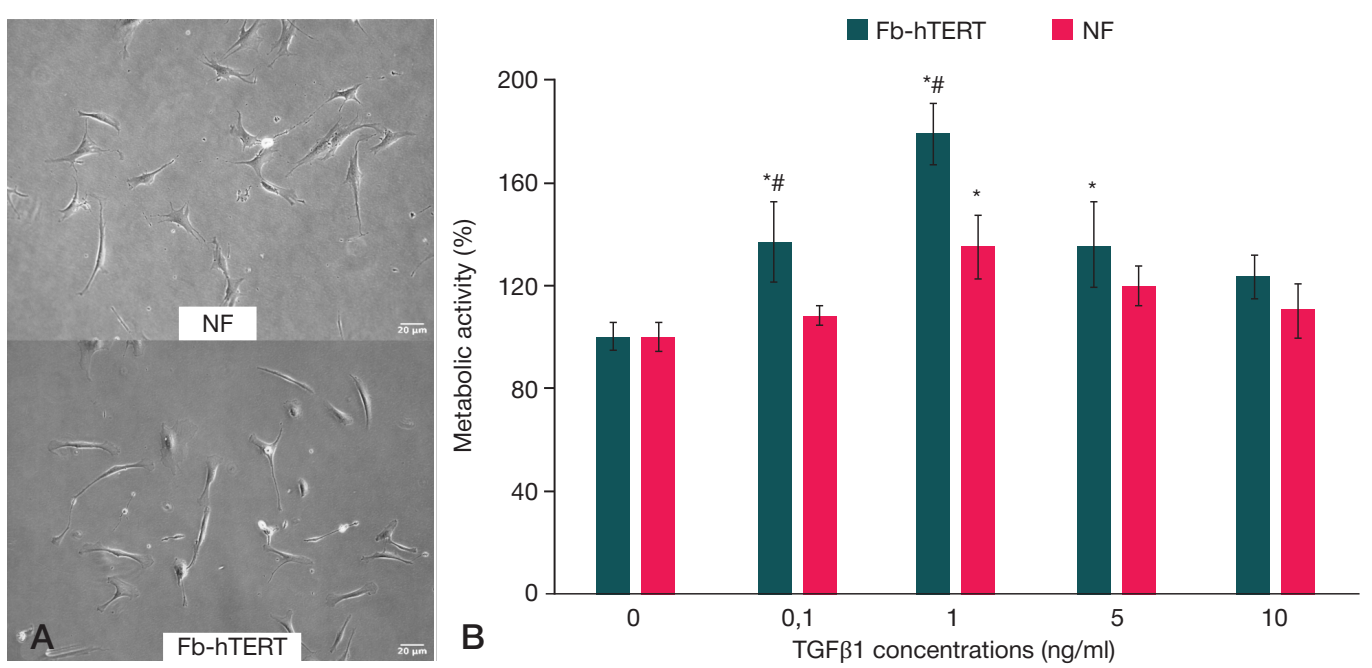

Fig. 1. Characteristics of NF and Fb-hTERT cells in a 2D-culture. A. The appearance of NF and Fb-hTERT cells. Light microscopy, $\times 100$ magnification. B. The metabolic activity of NF and Fb-hTERT cells at different concentrations of TGF $\beta 1$ (the MTT-assay). ${ }^{*}$ - differences are significant relative to the previous TGF $\beta 1$ concentration ( $p<$ 0.05); \# - differences are significant relative to NF cells at the same TGF $\beta 1$ concentration $(p<0.05)$. Note: hereinafter, NF stands for normal human foreskin fibroblast cells, Fb-hTERT stands for human skin telomerized postnatal fibroblasts 


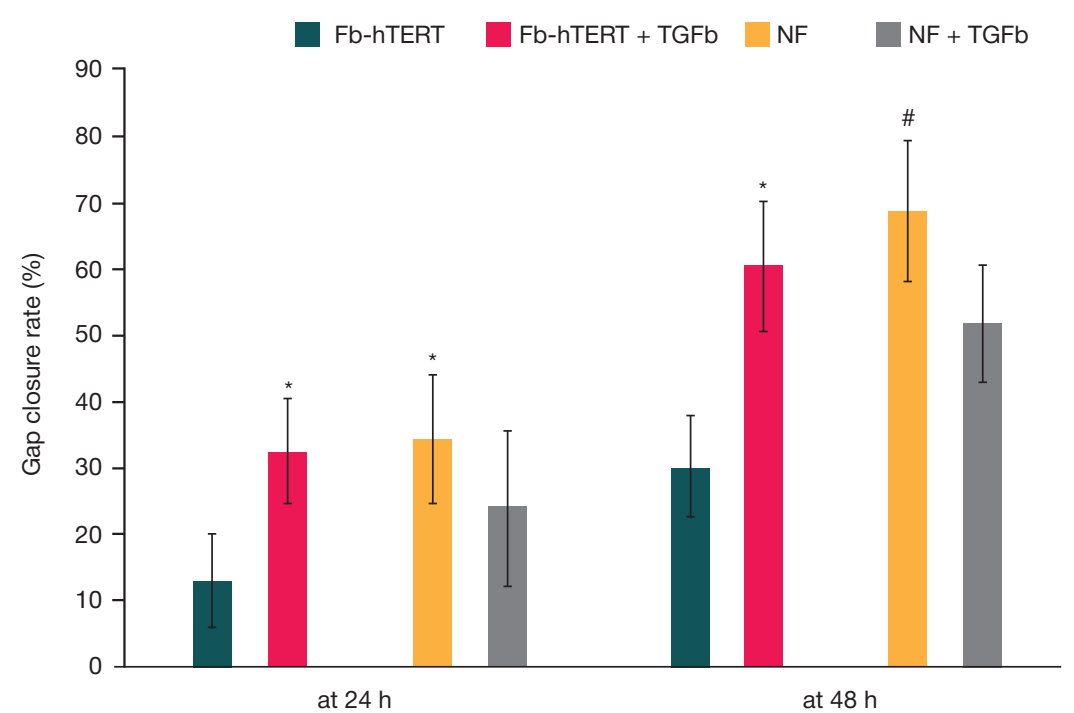

Fig. 2. Basal (control) and TGF $\beta 1$-stimulated gap closure rate in the monolayer of NF and Fb-hTERT cells (the scratch assay, TGF $\beta 1$ concentration in the culture medium is $1 \mathrm{ng} / \mathrm{ml})$. * - differences are significant relative to the basal gap closure rate $(p<0.05)$; \# - differences are significant relative to Fb-hTERT cells under the same culture conditions $(p<0.05)$

was observed following exposure to $1 \mathrm{ng} / \mathrm{ml}$ of TGF $\beta 1$ and was significantly higher for Fb-hTERT cells (179 $\pm 12 \%$ vs. $135 \pm 13 \%$, respectively; $p<0.05)$. A further increase in TGF $\beta 1$ concentrations added to the culture medium caused a decline in the metabolic activity of the cells relative to the effect exerted by $1 \mathrm{ng} / \mathrm{ml}$ TGF $\beta 1$. Therefore, we decided to use $1 \mathrm{ng} / \mathrm{ml} \mathrm{TGF} \beta 1$ to boost cell profibrogenic activity in the subsequent experiments.

The scratch assay demonstrated that the gap closure rate was different for the NF and Fb-hTERT cells and in the presence of TGF $\beta 1$ (Fig. 2).

The gap closure rate at $24 \mathrm{~h}$ and $48 \mathrm{~h}$ after creating the scratch was significantly higher in the monolayer of the control NF cells (in the absence of TGF $\beta 1$ ) than in the control Fb-hTERT cells. At the same time, the gap closure rate did not differ significantly between the NF cells cultured in the presence of TGF $\beta 1$ and the control cells. Stimulated by TGF $\beta 1$, the Fb-hTERT monolayer closed the scratch two times faster than the control cells at both time checkpoints: $24 \mathrm{~h}(33 \pm 8 \%$ and $13 \pm 7 \%$ respectively) and $48 \mathrm{~h}(61 \pm 10 \%$ and $30 \pm 7 \%$, respectively). Thus, in the absence of TGF $\beta 1$, NF cells closed the scratch in the monolayer faster than Fb-hTERT cells, whereas in the presence of TGF $\beta 1$, the Fb-hTERT monolayer recovered faster than the NF monolayer.

Spheroids were grown from 5,10 and 20 thousand fibroblast cells. In all cases, spheroids were shrinking in size during the first 5 days of culture. After that, their size remained relatively stable (Fig. 3A). The more cells were used to grow a spheroid, the more pronounced was the rate of shrinking, for both NF and Fb-hTERT cells.

Fb-hTERT spheroids were approximately two times larger than NF spheroids although Fb-hTERT cells themselves were smaller than NF.

TGF $\beta 1$ effects on NF and Fb-hTERT spheroids were studied using cellular aggregates formed by 20,000 (NF) and 10,000 cells (Fb-hTERT) (Fig. 3B). The sizes of the grown spheroids were comparable. The size is a crucial parameter for cell aggregates since it determines nutrient availability at the margin and in the center and affects the intensity of hypoxia in the center of the spheroid.

Spheroids grown from NF significantly increased in size $24 \mathrm{~h}$ after the culture medium was supplemented with $1 \mathrm{ng} / \mathrm{ml}$ TGF $\beta 1$, as compared with the control NF spheroids (Fig. 4).

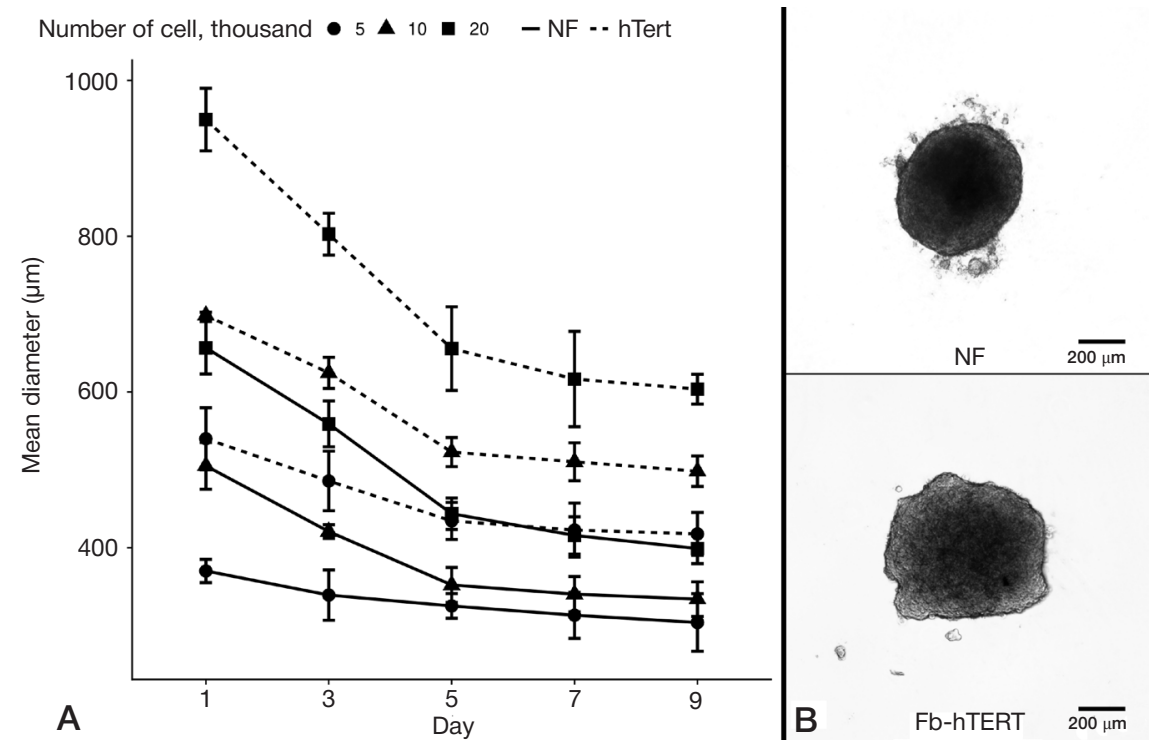

Fig. 3. Growing spheroids from NF and Fb-hTERT cells. A. Changes in the mean spheroid diameter grown from initially different numbers of NF and Fb-hTERT cells $(\mathrm{M} \pm \sigma)$. B. The appearance of an NF spheroid (20,000 cells) and an Fb-hTERT spheroid (10,000 cells). Light microscopy, $\times 40$ magnification 


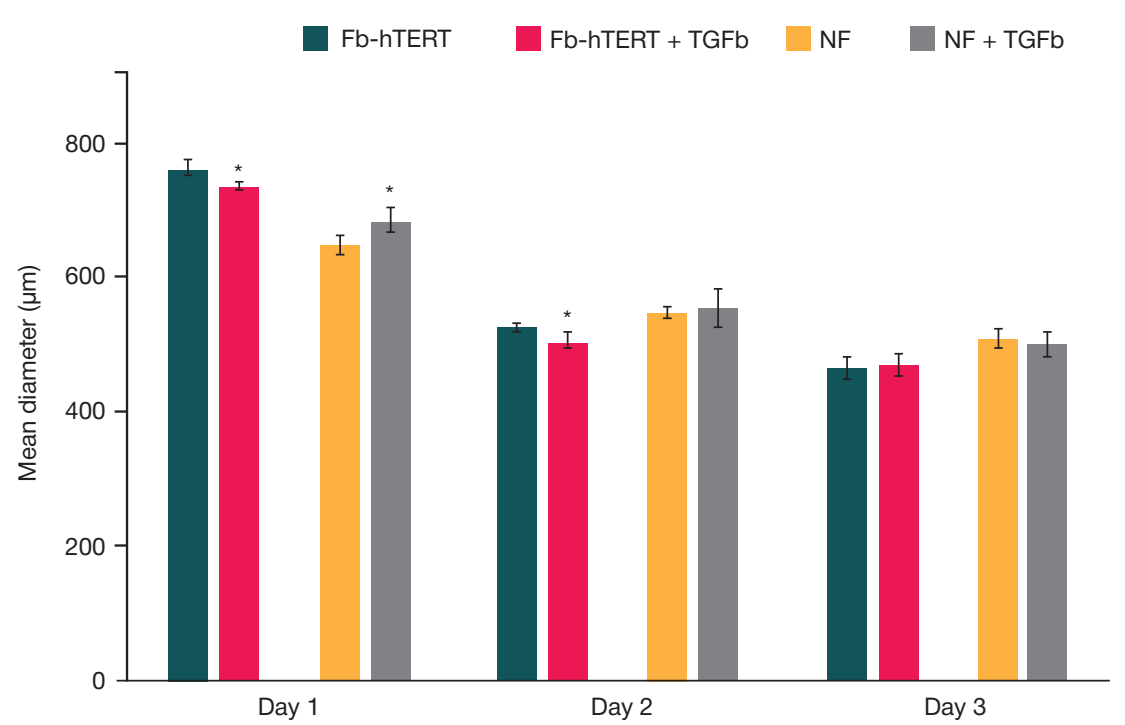

Fig. 4. The mean diameter of spheroids grown from NF and Fb-hTERT at different incubation times in the presence of $1 \mathrm{ng} / \mathrm{ml}$ TGF $\beta 1$ in the culture medium and in the absence of this growth factor (control). In order to obtain spheroids comparable in their size, we used 20,000 NF and 10,000 Fb-hTERT cells, respectively. ${ }^{\star}-$ differences are significant relative to the control group at the same time point $(p<0.05)$

After that, the differences started to level out and disappeared by day 3 of culture.

Spheroids grown from Fb-hTERT cells displayed a different behavior. In the presence of TGF $\beta 1$, they significantly diminished in size on days 1 and 2 of culture, in comparison with the control. By day 3, these differences smoothed out.

Slight differences in the size dynamics of spheroids formed from NF and Fb-hTERT cells at the early stages of the culture exposed to TGF $\beta 1$ might be explained by the phenotypic traits of the used cell lines and differences in their initial number. However, by day 3, as the spheroids grew and the cell density increased, there were almost no differences.

$\mathrm{NF}$ and Fb-hTERT cells differed in the expression of genes associated with fibrous tissue growth both in the absence or presence of TGF $\beta 1$ (Fig. 5).

In the absence of TGF $\beta 1$, NF cells tended to increasingly express the genes coding for collagen I and III, unlike FbhTERT cells, which expressed PAl-1 slightly more actively. The expression of the gene coding for fibronectin synthesis was comparable between NF and Fb-hTERT.

NF cells incubated for 2 days in the presence of $1 \mathrm{ng} / \mathrm{ml}$ TGF $\beta 1$ exhibited a tendency for increased expression of all studied genes, in comparison with the control. Significant differences were observed for the gene coding for fibronectin synthesis.

At the same time, no significant changes were observed in the expression of COL1A1, COL3A1, FN1, and PAI-1 in Fb-hTERT cells incubated with TGF $\beta 1$.

Those differences between the basal and TGF $\beta 1$-stimulated expression of collagen I by NF and Fb-hTERT cells were also present in spheroid cultures (Fig. 6A). According to microscopy findings, the level of collagen expression in the spheroids derived from NF was significantly higher than in the spheroids formed from Fb-hTERT cells (Fig. 6B). When NF-spheroids were incubated with TGF $\beta 1$, there was a 1.7-fold increase in collagen I production, whereas for Fb-hTERT-derived spheroids cultured under the same conditions the increase in the production of collagen I was moderate (1.4-fold).

\section{DISCUSSION}

We have been exploring the possibility of stimulating the profibrogenic potential of normal and telomerized human skin fibroblasts (NF and Fb-hTERT, respectively) in vitro. It is known that telomerase is active in fibroblasts isolated from keloid scars

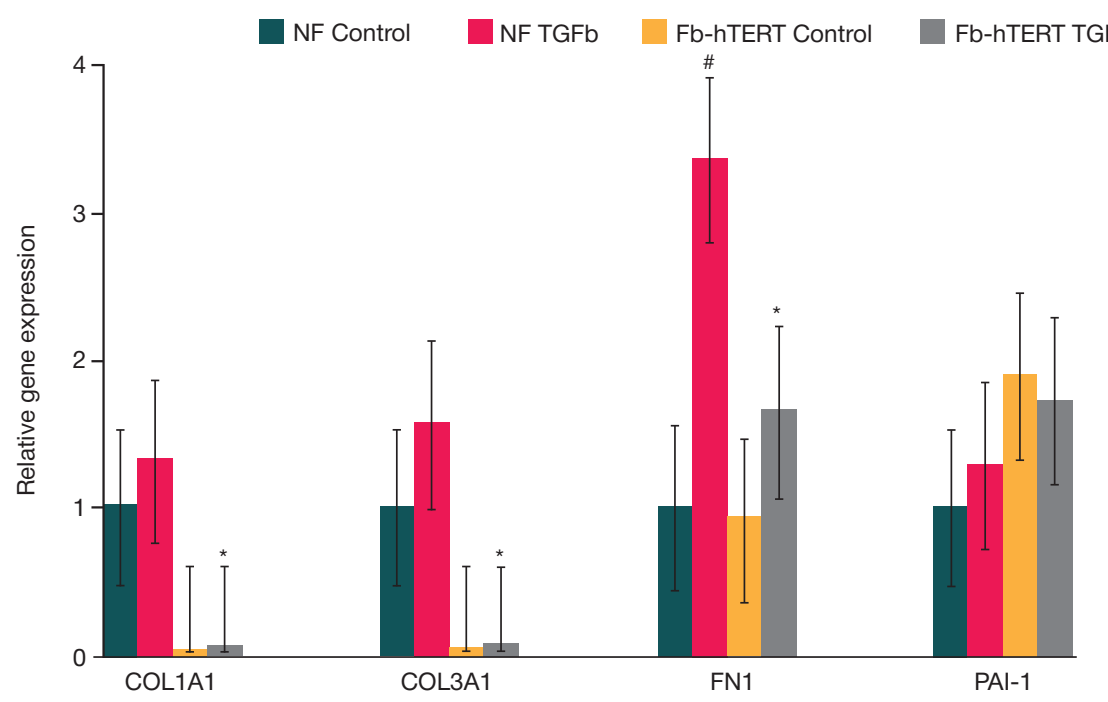

Fig. 5. Expression of genes associated with fibrous tissue growth in NF and Fb-hTERT cells in the absence and presence of TGF $\beta 1$ (1 ng/ml). * — differences are significant between Fb- hTERT and NF cells in the presence of TGF $\beta 1(p<0.05)$; \# - differences are significant between the 2 cell lines in the absence and in the presence of TGF $\beta 1(p<0.05)$ 

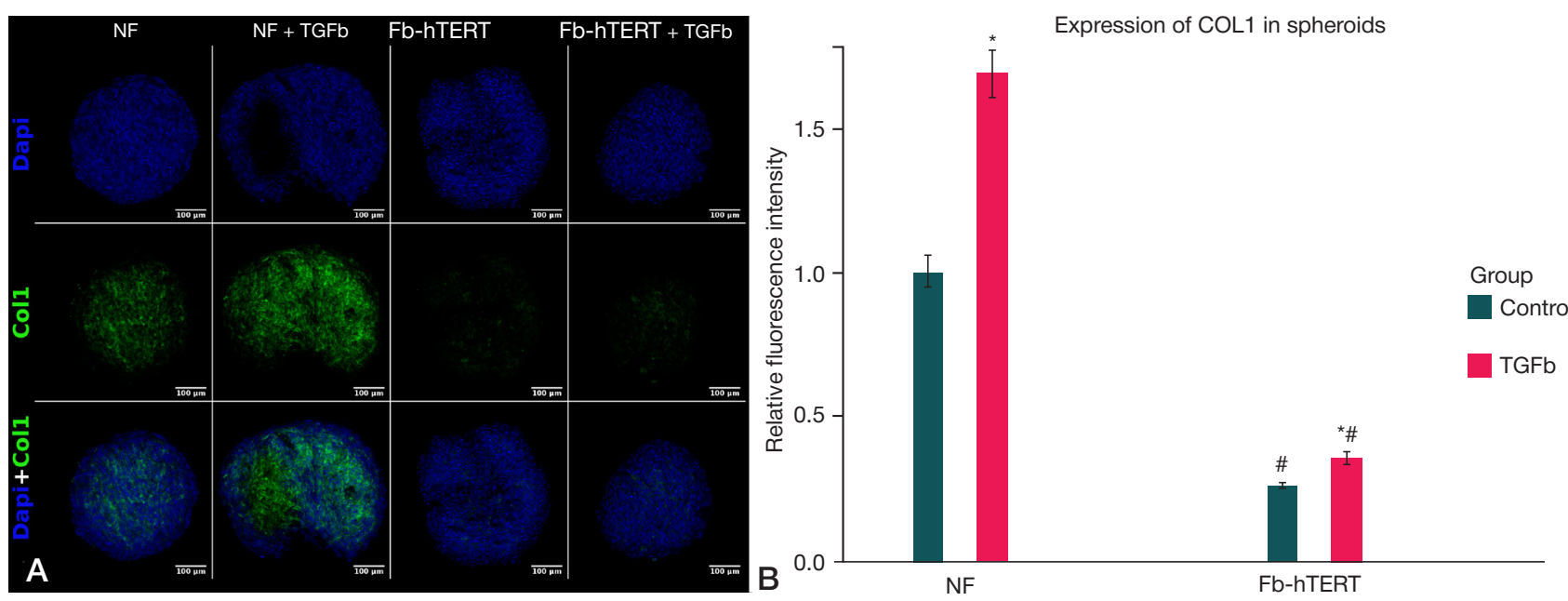

Fig. 6. Collagen I production in the spheroids grown from NF and Fb-hTERT cells in the presence of $1 \mathrm{ng} / \mathrm{ml}$ TGF $\beta 1$. A. Immunofluorescence assay, laser confocal microscopy, $\times 100$ magnification; cell nuclei are stained blue (Dapi), collagen I is stained green. B. Relative fluorescence intensity of collagen I in the spheroids formed by NF and Fb-hTERT cells in the presence of $1 \mathrm{ng} / \mathrm{ml} \mathrm{TGF} \beta 1 .{ }^{*}$ — indicates statistically significant differences in collagen I fluorescence intensity in spheroids cultured in the presence or absence of TGF $\beta 1(p<0.05)$; \# — indicates statistically significant differences in collagen I fluorescence intensity between Fb-hTERT spheroids and NF spheroids in the presence of TGF $\beta 1(p<0.05)$

[6]. In terms of telomerase activity, keloid fibroblasts resemble immortalized cells; therefore, Fb-hTERT make a promising in vitro candidate model for pathological keloid and hypertrophic scars. At the same time, according to the literature, the phenotype of normal fibroblasts can be modified to approximate the phenotype of cells isolated from pathological scars by using growth factors that play a key role in the pathogenesis of pathologic fibrous growth; one of such growth factors is TGF $\beta 1$ [16]. TGF $\beta 1$ activates a variety of signal cascades triggering increased cell proliferation, adhesion and migration, as well as extracellular matrix production [17].

Importantly, in vitro models of any tissue type, including normal and fibrous connective tissue of scars, must reproduce its 3D structure ensuring natural cell-cell interactions and mutual influences. Therefore, the phenotypic traits of NF and Fb-hTERT cells were investigated in spheroid cultures. This model is actively used in carcinogenesis research and in the studies evaluating the efficacy of anticancer therapies as tumor microenvironments, nutrient supply, gas exchange and physiology is best reproduced in cellular spheroids [18]. However, prior to our experiment, spheroids had not been used for creating a cell model of a pathologic hypertrophic or keloid scar, which indicates the novelty of our findings.

On the whole, intact Fb-hTERT cells, as compared with NF, had a number of phenotypic traits typical to immortalized cells: a smaller size, a higher doubling rate and a higher rate of confluent monolayer formation, which was, perhaps, determined by their high proliferative activity. This feature of Fb-hTERT cells might underlie their higher (as compared to NF cells) metabolic activity both in the absence or presence of TGF $\beta 1$ (according to the MTT assay results).

An MTT assay allows assessing the metabolic and arguably — proliferative activity of cells [19]. In this study, we have demonstrated a dose-dependent effect exerted by TGF $\beta 1$ on the metabolic activity of NF and Fb-hTERT, which was more pronounced for Fb-hTERT cells. This finding is consistent with other reports of TGF $\beta 1$ effects on the proliferative and metabolic activity of fibroblasts $[20,21]$. In our study, the peak increase of cell metabolic activity was observed following exposure to $1 \mathrm{ng} / \mathrm{ml}$ TGF $\beta 1$ and was more pronounced in Fb-hTERT cells.

The size dynamics of growing spheroids was consistent with other reports $[22,23]$ of spheroids shrinking in size on the first day of culture and then plateauing gradually (spheroid maturation). Unsurprisingly, our spheroids derived from the initially greater number of cells (especially those grown from 20,000 cells) showed a sharper reduction in size, because the optimal diameter of a cellular spheroid is determined by nutrient supply and adequate gas exchange and ranges from 200 to $500 \mu \mathrm{m}$ [24].

Spheroids formed from Fb-hTERT cells were significantly larger than NF-derived spheroids, although NF cells are bigger than Fb-hTERT cells. This was probably the result of higher proliferative activity normally observed in telomerized cells. At the same time, we cannot rule out that Fb-hTERT spheroids were less capable of retraction due to weak cell-cell contacts.

Exposure to TGF $\beta 1$ decreased the size of Fb-hTERT spheroids and also increased the rate of gap closure (in the scratch test), which was lower in intact Fb-hTERT cells than in NF. Perhaps, TGF $\beta 1$ not only stimulated Fb-hTERT proliferation but also promoted their adhesion capacity and facilitated cell cooperation. However, this question requires further investigation.

Importantly, Fb-hTERT cells had other phenotypic traits distinguishing them from normally differentiated fibroblasts. For example, production of basic proteins specific to fibroblasts that are building blocks for connective tissue fibers (collagen I and III, fibronectin) was lower in Fb-hTERT cells than in NF (both intact or exposed to TGF $\beta 1$ ); this was also true for spheroid cultures, as demonstrated by PCR-based assays and fluorescent staining. Because Fb-hTERT are an immortalized cell line, their proliferation programs seem to be far more active than differentiation programs. Consequently, the expression of collagen genes (characteristic of differentiated connective tissue cells) was low in both intact and TGF $\beta 1$-stimulated cells. At the same time, when exposed to TGF $\beta 1$, NF cells demonstrated the phenotype of differentiated cells with increased expression of extracellular matrix-related genes.

It is known that the expression of genes involved in the synthesis of connective tissue components is increased in keloid scars. There are reports of increased transcription and translation of collagens I and III and fibronectin in fibrous growths [2]. The abundance of collagen in keloid tissue is explained by the increased expression of PAl-1 not typically seen in normal fibroblasts [25]. Of note, PAl-1 expression in intact Fb-hTERT cells observed in our experiment was higher than in NF.

Besides, the scratch in the monolayer of intact NF cells closed faster than in Fb-hTERT cells. The scratch test is used for the indirect assessment of cell regeneration potential (the ability 
to close a wound). The gap closure rate depends on the levels of cell proliferation and/or migration. It is known that TGF $\beta 1$ promotes wound healing [17]. In our experiments, exposure to TGF $\beta 1$ allowed the Fb-hTERT monolayer (but not the NF monolayer) to recover more rapidly. This finding needs to be further analyzed in Fb-hTERT and NF cultures by evaluating the effects of TGF $\beta 1$ on cell adhesion and cooperation programs involved in the implementation of cell capacity to migrate.

\section{CONCLUSION}

Telomerized fibroblasts have a few phenotypic traits observed in keloid fibroblasts: high proliferative and metabolic activity; the ability to close a gap in the monolayer (the scratch assay) in the presence of TGF $\beta 1$; increased, as compared to NF, levels of PAl-1 expression (trending, statistically insignificant). Other important features include their ability to divide infinitely, maintain phenotypic homogeneity at high passage numbers and form cell spheroids. This makes temolerized fibroblasts a promising candidate for the 3D modeling of pathologic scars. However, the expression of proteins associated with extracellular matrix production (COL1A1, COL3A1, FN1) is low in telomerized fibroblasts, including in the presence of TGF $\beta 1$, whereas keloid fibroblasts are characterized by overproduction of these proteins. This fact should be accounted for when exploiting Fb-hTERT cells for modeling hypertrophic scars. Further research is needed to study the possibility of activating the expression of extracellular matrix proteins in these cells.

\section{References}

1. Jumper N, Paus R, Bayat A. Functional histopathology of keloid disease. Histology and histopathology. 2015; 30 (9): 1033-57.

2. Sidgwick GP, Bayat A. Extracellular matrix molecules implicated in hypertrophic and keloid scarring. Journal of the European Academy of Dermatology and Venereology. 2012; 26 (2): 141-152.

3. Liang CJ, Yen YH, Hung LY, Wang SH, Pu CM, Chien HF, et al. Thalidomide inhibits fibronectin production in TGF- $\beta 1$-treated normal and keloid fibroblasts via inhibition of the p38/Smad3 pathway. Biochemical pharmacology. 2013; 85 (11): 1594-02.

4. De Felice B, Wilson RR, Nacca M. Telomere shortening may be associated with human keloids. BMC medical genetics. 2009; 10 (1): 110.

5. Huang $Y$, Lin LX, Bi QX, Wang P, Wang XM, Liu J, et al. Effects of hTERT antisense oligodeoxynucleotide on cell apoptosis and expression of hTERT and bcl-2 mRNA in keloid fibroblasts. European Review for Medical and Pharmacological Sciences. 2017; 21 (8): 1944-51.

6. Yu D, Shang Y, Yuan J, Ding S, Luo S, Hao L. Wnt/ $\beta$-catenin signaling exacerbates keloid cell proliferation by regulating telomerase. Cellular Physiology and Biochemistry. 2016; 39 (5): 2001-13.

7. Kischer CW, Thies AC, Chvapil M. Perivascular myofibroblasts and microvascular occlusion in hypertrophic scars and keloids. Human pathology. 1982; 13 (9): 819-24.

8. Bran GM, Goessler UR, Hormann K, Riedel F, Sadick H. Keloids: current concepts of pathogenesis. International journal of molecular medicine. 2009; 24 (3): 283-93

9. Chin D, Boyle GM, Parsons PG, Coman WB. What is transforming growth factor-beta (TGF- $\beta$ )?. British journal of plastic surgery. 2004; 57 (3): 215-21.

10. Yang GP, Lim IJ, Phan TT, Lorenz HP, Longaker MT. From scarless fetal wounds to keloids: molecular studies in wound healing Wound repair and regeneration. 2003; 11 (6): 411-8.

11. Jagadeesan J, Bayat $A$. Transforming growth factor beta (TGF $\beta$ ) and keloid disease. International journal of surgery. 2007; 5 (4): 278-85.

12. Egorov EE, Terekhov SM, Vishniakova K, Karachentsev DN, Kazimirchuk EV, Tsvetkova TG, et al. Telomerization as a method of obtaining immortal human cells preserving normal properties. Ontogenez. 2003; 34 (3): 183.

13. Kupcsik L. Estimation of cell number based on metabolic activity: the MTT reduction assay. In Mammalian cell viability. Humana Press. 2011: 13-19.

\section{Литература}

1. Jumper N, Paus R, Bayat A. Functional histopathology of keloid disease. Histology and histopathology. 2015; 30 (9): 1033-57.

2. Sidgwick GP, Bayat A. Extracellular matrix molecules implicated in hypertrophic and keloid scarring. Journal of the European Academy of Dermatology and Venereology. 2012; 26 (2): 141-152.
14. Schindelin J, Arganda-Carreras I, Frise E, Kaynig V, Longair M, Pietzsch T, et al. Fiji: an open-source platform for biological-image analysis. Nature methods. 2012; 9 (7): 676-82.

15. Carpenter AE, Jones TR., Lamprecht MR, Clarke C, Kang IH, Friman $\mathrm{O}$, et al. CellProfiler: image analysis software for identifying and quantifying cell phenotypes. Genome biology. 2006; 7 (10): R100.

16. Lee TY, Chin GS, Kim W, Chau D, Gittes GK, Longaker MT. Expression of transforming growth factor beta 1, 2, and 3 proteins in keloids. Annals of plastic surgery. 1999; 43 (2): 179-84.

17. Klass BR, Grobbelaar AO, Rolfe KJ. Transforming growth factor $\beta 1$ signalling, wound healing and repair: a multifunctional cytokine with clinical implications for wound repair, a delicate balance. Postgraduate Medical Journal. 2009; 85 (999): 9-14.

18. Friedrich J, Ebner R, Kunz-Schughart LA. Experimental anti-tumor therapy in 3-D: spheroids-old hat or new challenge? International journal of radiation biology. 2007; 83 (11-12): 849-71.

19. Ohno M, Abe T. Rapid colorimetric assay for the quantification of leukemia inhibitory factor (LIF) and interleukin-6 (IL-6). Journal of immunological methods. 1991; 145 (1-2): 199-203.

20. Meran S, Thomas DW, Stephens P, Enoch S, Martin J, Steadman R, et al. Hyaluronan facilitates transforming growth factor- $\beta 1$-mediated fibroblast proliferation. Journal of Biological Chemistry. 2008; 283 (10): 6530-45.

21. Negreros M, Hagood JS, Espinoza CR, Balderas-Martínez YI, Selman M, Pardo A. Transforming growth factor beta 1 induces methylation changes in lung fibroblasts. PloS one. 2019; 14 (10): e0223512.

22. Takezawa T, Mori Y, Yonaha T, Yoshizato K. Characterization of morphology and cellular metabolism during the spheroid formation by fibroblasts. Experimental cell research. 1993; 208 (2): 430-41.

23. Frandsen SK, Gibot L, Madi M, Gehl J, Rols MP. Calcium electroporation: evidence for differential effects in normal and malignant cell lines, evaluated in a 3D spheroid model. PLoS One. 2015; 10 (12): e0144028.

24. Mittler F, Obeïd P, Rulina AV, Haguet V, Gidrol X, Balakirev MY. High-content monitoring of drug effects in a 3D spheroid model. Frontiers in oncology. 2017; 7: 293.

25. Tuan TL, Wu H, Huang EY, Chong SS, Laug W, Messadi D, et al. Increased plasminogen activator inhibitor- 1 in keloid fibroblasts may account for their elevated collagen accumulation in fibrin gel cultures. The American journal of pathology. 2003; 162 (5): 1579-89.

3. Liang CJ, Yen YH, Hung LY, Wang SH, Pu CM, Chien HF, et al Thalidomide inhibits fibronectin production in TGF- $\beta 1$-treated normal and keloid fibroblasts via inhibition of the p38/Smad3 pathway. Biochemical pharmacology. 2013; 85 (11): 1594-02.

4. De Felice B, Wilson RR, Nacca M. Telomere shortening may be 
associated with human keloids. BMC medical genetics. 2009; 10 (1): 110.

5. Huang $Y$, Lin LX, Bi QX, Wang P, Wang XM, Liu J, et al. Effects of hTERT antisense oligodeoxynucleotide on cell apoptosis and expression of hTERT and bcl-2 mRNA in keloid fibroblasts. European Review for Medical and Pharmacological Sciences. 2017; 21 (8): 1944-51.

6. Yu D, Shang Y, Yuan J, Ding S, Luo S, Hao L. Wnt/B-catenin signaling exacerbates keloid cell proliferation by regulating telomerase. Cellular Physiology and Biochemistry. 2016; 39 (5): 2001-13.

7. Kischer CW, Thies AC, Chvapil M. Perivascular myofibroblasts and microvascular occlusion in hypertrophic scars and keloids. Human pathology. 1982; 13 (9): 819-24.

8. Bran GM, Goessler UR, Hormann K, Riedel F, Sadick H. Keloids: current concepts of pathogenesis. International journal of molecular medicine. 2009; 24 (3): 283-93

9. Chin D, Boyle GM, Parsons PG, Coman WB. What is transforming growth factor-beta (TGF- $\beta$ )?. British journal of plastic surgery. 2004; 57 (3): 215-21.

10. Yang GP, Lim IJ, Phan TT, Lorenz HP, Longaker MT. From scarless fetal wounds to keloids: molecular studies in wound healing. Wound repair and regeneration. 2003; 11 (6): 411-8.

11. Jagadeesan J, Bayat A. Transforming growth factor beta (TGF $\beta$ and keloid disease. International journal of surgery. 2007; 5 (4): 278-85.

12. Egorov EE, Terekhov SM, Vishniakova K, Karachentsev DN Kazimirchuk EV, Tsvetkova TG, et al. Telomerization as a method of obtaining immortal human cells preserving normal properties. Ontogenez. 2003; 34 (3): 183

13. Kupcsik L. Estimation of cell number based on metabolic activity: the MTT reduction assay. In Mammalian cell viability. Humana Press. 2011: 13-19.

14. Schindelin J, Arganda-Carreras I, Frise E, Kaynig V, Longair M, Pietzsch T, et al. Fiji: an open-source platform for biological-image analysis. Nature methods. 2012; 9 (7): 676-82.

15. Carpenter AE, Jones TR., Lamprecht MR, Clarke C, Kang $\mathbb{H}$, Friman O, et al. CellProfiler: image analysis software for identifying and quantifying cell phenotypes. Genome biology. 2006; 7 (10): R100.

16. Lee TY, Chin GS, Kim W, Chau D, Gittes GK, Longaker MT. Expression of transforming growth factor beta 1,2, and 3 proteins in keloids. Annals of plastic surgery. 1999; 43 (2): 179-84.

17. Klass BR, Grobbelaar AO, Rolfe KJ. Transforming growth factor $\beta 1$ signalling, wound healing and repair: a multifunctional cytokine with clinical implications for wound repair, a delicate balance. Postgraduate Medical Journal. 2009; 85 (999): 9-14.

18. Friedrich J, Ebner R, Kunz-Schughart LA. Experimental anti-tumor therapy in 3-D: spheroids-old hat or new challenge? International journal of radiation biology. 2007; 83 (11-12): 849-71.

19. Ohno M, Abe T. Rapid colorimetric assay for the quantification of leukemia inhibitory factor (LIF) and interleukin-6 (IL-6). Journal of immunological methods. 1991; 145 (1-2): 199-203.

20. Meran S, Thomas DW, Stephens P, Enoch S, Martin J, Steadman R, et al. Hyaluronan facilitates transforming growth factor- $\beta 1$-mediated fibroblast proliferation. Journal of Biological Chemistry. 2008; 283 (10): 6530-45.

21. Negreros M, Hagood JS, Espinoza CR, Balderas-Martínez YI, Selman M, Pardo A. Transforming growth factor beta 1 induces methylation changes in lung fibroblasts. PloS one. 2019; 14 (10): e0223512.

22. Takezawa T, Mori Y, Yonaha T, Yoshizato K. Characterization of morphology and cellular metabolism during the spheroid formation by fibroblasts. Experimental cell research. 1993; 208 (2): 430-41.

23. Frandsen SK, Gibot L, Madi M, Gehl J, Rols MP. Calcium electroporation: evidence for differential effects in normal and malignant cell lines, evaluated in a 3D spheroid model. PLoS One. 2015; 10 (12): e0144028.

24. Mittler F, Obeïd P, Rulina AV, Haguet V, Gidrol X, Balakirev MY. High-content monitoring of drug effects in a 3D spheroid model. Frontiers in oncology. 2017; 7: 293.

25. Tuan TL, Wu H, Huang EY, Chong SS, Laug W, Messadi D, et al. Increased plasminogen activator inhibitor-1 in keloid fibroblasts may account for their elevated collagen accumulation in fibrin gel cultures. The American journal of pathology. 2003; 162 (5): 1579-89. 